\title{
A study on genus ganoderma from deciduous forests of Odisha, India
}

\author{
Abstract \\ The present paper deals with the collection of Ganoderma species from various \\ deciduous forests of Odisha, India. The four species of the genus, namely, G. lucidum, \\ G. applanatum, G. tsugae, G. australe were studied for their macroscopic features and \\ illustrated here.
}

Keywords: g. lucidum, g. applanatum, g. tsugae, g. australe, deciduous forests
Volume I Issue 2 - 2015

\author{
Sushri Shanta Tripathy, Nibha Gupta \\ Division of Plant Pathology \& Microbiology, Regional Plant \\ Resource Centre, India.
}

Correspondence: Sushri Shanta Tripathy, Division of Plant Pathology \& Microbiology, Regional Plant Resource Centre, India,Tel+919438651955, Email sushri27tripathy@gmail.com

Received: July 16, 2015 | Published: September 09, 2015

\section{Introduction}

Ayurveda is the oldest system of medicine in India that describes medicinal uses of several plants and very few mushrooms and wood rotting fungi. Some of the clinically used drugs such as aspirin, digitoxin, progesterone, cortisone, morphine, vincristine, vinblastine, taxol and several others are derived directly or indirectly from higher plants. Clinically important and well recognized drugs of fungal origin are penicillin, griseofulvin, ergot alkaloids and cyclosporine. They are widely distributed in India on tree trunks. For 4000 years G. lucidum has been used as a part of Chinese and Japanese medicine especially for the treatment of most of the human ailments. Extracts from the fruiting bodies and mycelia of G. lucidum occurring in South India were found to possess in vitro antioxidant activity. Indian mycologists started studying the fungi from the beginning of $20^{\text {th }}$ century. Montagne ${ }^{1}$ was the first person to report members of Agaricales from India. Studies on agarics of north India were first carried out in north eastern Himalayas by Berkeley. ${ }^{2}$ After this period of intensive work by European and American researchers, there was a significant decrease in taxonomic studies on Indian Agaricales till 1960s. Ganoderma is the largest genus in the order Aphyllophorales with more than 300 species. It is known to cause root or butt rot of the hardwood trees and it is also known as medicinally important "mushroom" in the Asian continent. As ectomycorrhizal fungi, mushrooms are important constituent of forest ecosystem growing on the most abundant bio-molecules of our biosphere i.e. cellulose. Now mushrooms including both edible and non edible are regarded as macro fungi with distinctive fruiting bodies which can be epigeous or hypogeous and are large enough to be seen through naked eyes. The family Ganodermataceae describes polypore basidiomycetous fungi having double-walled basidiospores. ${ }^{3}$ Basidiocarps of this genus have a laccate (shiny) surface that is associated with the presence of thick walled pilocystidia embedded in an extracellular melanin matrix. ${ }^{4}$ The Eastern Ghats are isolated hill ranges in peninsular India (Andhra Pradesh, Orissa, Tamil Nadu, and Karnataka) harboring between 11 $30^{\prime}$ to $210^{\prime} \mathrm{N}$ latitudes and $7722^{\prime}$ to $8520^{\prime} \mathrm{E}$ longitudes, primarily tropical moist deciduous vegetation which represents species of high economic value with potentials for timber and medicines. Eastern Ghats are highly significant in terms of biodiversity. Of the estimated 3,200 flowering plant taxa, there are about 528 tree taxa under 271 genera belonging to 80 regions of Eastern Ghats. In total, 454 species from fewer than 243 genera and 78 families are endemic to
Eastern Ghats. Based on geological and tectonic consideration, the Eastern Ghats in Orissa start from North of Similipal in Mayurbhanj districts and run through Malkangiri. Seventeen districts of Orissa comes under the eastern Ghats including 14 protected areas (13 wild life sanctuaries, one biosphere reserve, one national park, two tiger reserves and one ramset wetland). According to Champion \& Seth, ${ }^{5}$ the vegetation of the hill is basically tropical moist deciduous type with many riparian evergreen elements. The average annual rainfall is $1485 \mathrm{~mm}$. The maximum temperature goes up to $42^{\circ} \mathrm{C}$ and the minimum temperature falls to $5^{\circ} \mathrm{C}$. The relative humidity is normally high during the monsoon and post-monsoon months. Sometimes more than $85 \%$ humidity favors the growth of macro fungi. Many of the streams originated from the top of the hill that provides multiple habitats to enhance the macro fungal diversity.

Ganoderma species are found all over the world, and different characteristics, such as shape and color (red, black, blue/green, white, yellow, and purple) of the fruit body, host specificity, and geographical origin, are used to identify individual members of the species. ${ }^{6-8}$ Owing to its irregular distribution in the wild and an increasing demand for G. lucidum as a medicinal herb, attempts were made to cultivate the fungus. ${ }^{9}$ The present study deals with the identification and occurrence of Ganoderma species in Odisha.

\section{Materials and methods}

\section{Field study}

The study was undertaken from August to November in 20102013, during period of seasonal monsoon. The sampling was conducted every month at regular intervals. The sites selected were the major forest divisions of Orissa, including Koraput Forest Division, Similipal Tiger Biosphere Reserve, Karlapat Sanctuary, Baliguda Forest Division and Banei Forest Division. The major forest divisions are tropical moist deciduous forests except Karlapat Sanctuary (dry deciduous forest) and Similipal Biosphere Reserve (semi green forest). All Ganoderma basidiocarps were stored in dried form as well as in formaldehyde solution, in the Mushroom Herbarium of Microbiology Division in Regional Plant Resource Centre, Bhubaneswar. In cases where fungi were not identified to the species level, numbers were given to the specimens belonging to the same genus. Identification of Ganoderma specimens was carried out based on their macroscopic characteristics i.e. habitat, occurrence, association, pileus diameter, 
context, colour, texture, odour; stipe length, context, attachment; and pore colour and lamellae ${ }^{10}$ (Figure 1).

\section{Species richness}

Species richness is a measure of the number of species found in a sample. Since the larger the sample, the more species we would expect to find, the number of species is divided by the square root of the number of individuals in a sample. $D=s / \sqrt{N}$ where $s$ equals the number of different species, and $\mathrm{N}$ equals the total number of individual organisms in a sample.

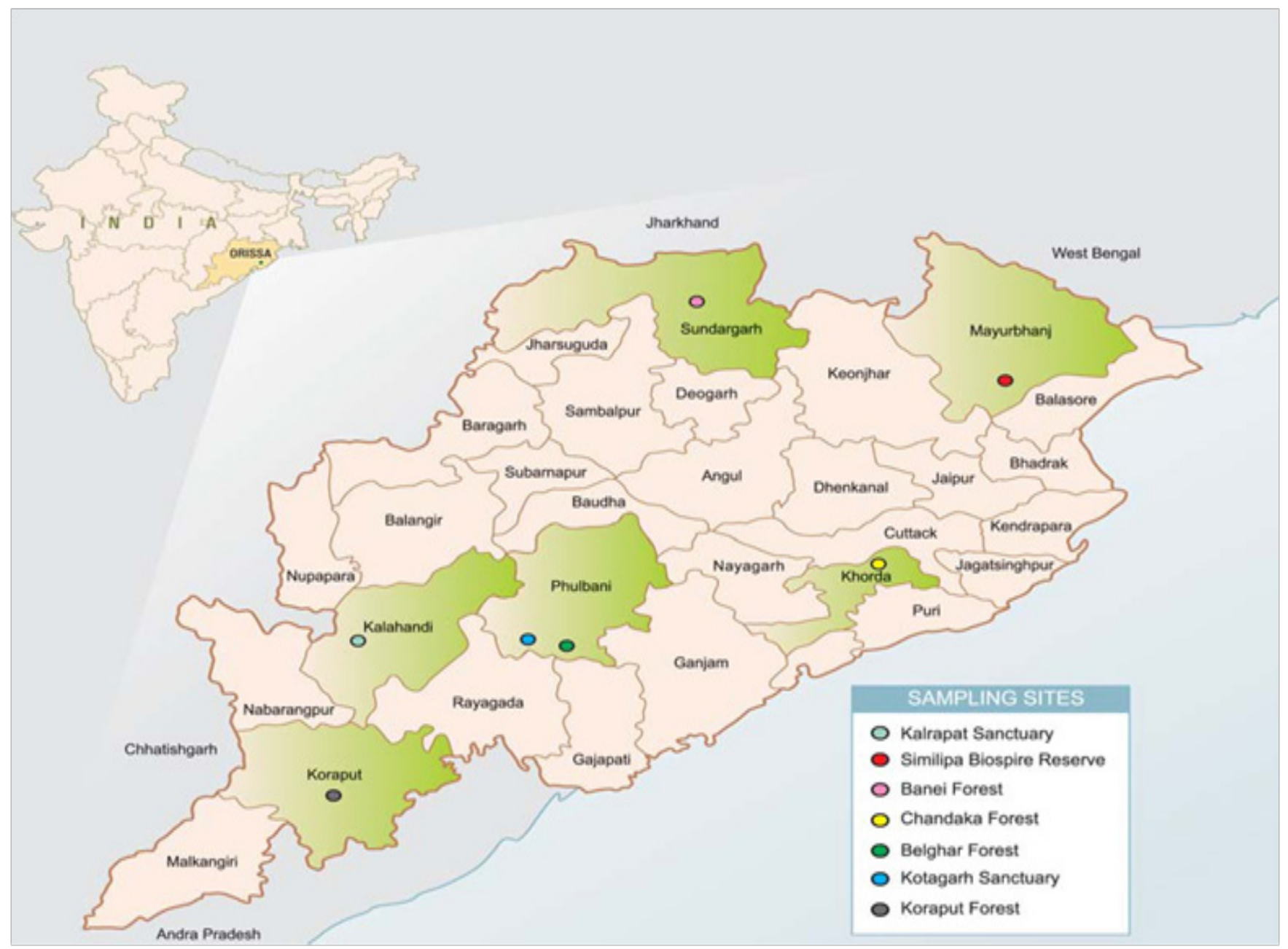

Figure I Map of sampling and study sites.

\section{Result and discussion}

\section{Ganoderma lucidum (Curtis) P. Karst}

a. Pileus: Diameter: $6 \mathrm{~cm}(\mathrm{av})$,

b. Colour: when young in centre: brown to turmeric yellow.

c. Margin: white; mature specimen: brown to white.

d. Shape: applanate.

e. Pileus margin roll: straight.

f. Pileus surface on touch: dry, hygrophanous.

g. Scales: appressed, cover the entire surface.

h. Colour of the scales: yellow to reddish brown,

i. Cuticle: not peeling.

j. Pileus consistency: brittle. k. Flesh colour: butter white; colour changes to pale yellow.

1. Stipe: sessile.

m. Pores: present.

n. Habitat: on decaying wood, Association: gregarious, present on slopes.

o. Soil characterstics : laterite soil.

p. Forest type: tropical moist deciduous.

q. Vegetational community: thick, woody.

r. Distribution: Due to its wide medicinal importance, it is being cultivated and used in most of the Asian countries including China, Japan, Endland, and Solan in Himachal Pradesh of India. It is used in tea as herb. It has anticancerous, anti-diabetic anti-cholesterol and immune modulatory properties. In Odisha, it is widely distributed in almost all forest divisions (Figure 2). 

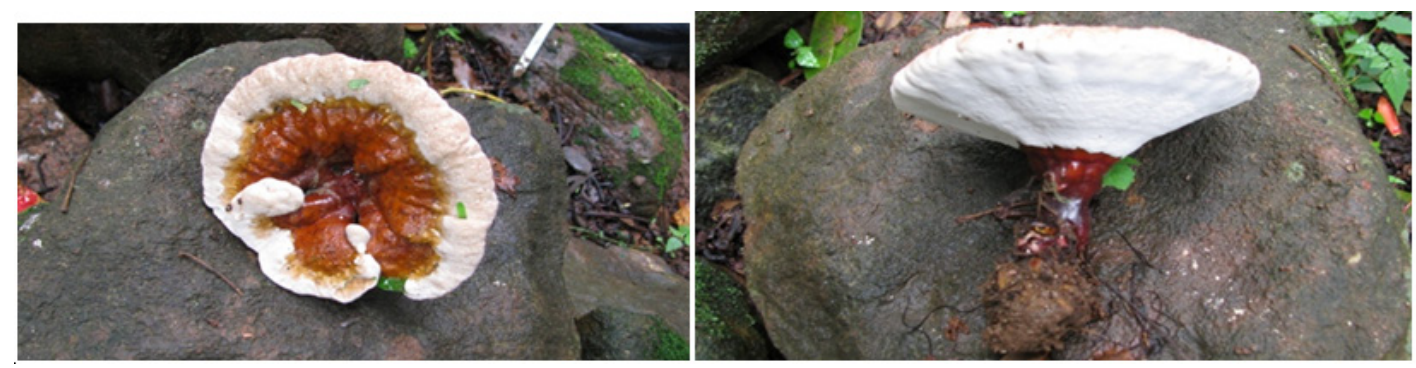

Figure 2 Photograph of Ganoderma lucidum in the field.

\section{Ganoderma lucidum}

\section{Ganoderma applanatum (Pers.) Pat}

a. Pileus: Diameter: $4 \mathrm{~cm}(\mathrm{av})$.

b. Colour: when young in centre: black.

c. Margin: white, mature Specimen; pure black in colour.

d. Shape: lateral, tuberculate.

e. Pileus margin roll: reflexed.

f. Pileus surface on touch: moist, hygrophanous.

g. Scales: appressed, cover the entire surface.

h. Cuticle: not peeling. Pileus consistency: brittle.

i. Flesh colour: deep brown, no change in colour on bruishing or handling.

j. Stipe: sessile.

k. Basal Association: mycorrhizal.

1. Lamellae: absent.

m. Pores: present.

n. Habitat: On tree trunk.

o. Association: scattered, present on slopes.

p. Soil characteristics: laterite soil.

q. Forest type: tropical moist deciduous. Vegetational community: grassland, thick woody.

r. Distribution: Distributed widely in Koraput Forest, Belghar Forest and Kotagarh Sanctuary and the route to moist deciduous forests towards Gurguria Forest of Similipal Biosphere Reserve (Figure 3).

\section{Ganoderma tsugae (Kuo, M.)}

a. Pileus: Diameter: $6 \mathrm{~cm}(\mathrm{av})$,

b. Colour: when young in centre: reddish brown, Margin: brown; mature specimen: reddish brown.

c. Shape: applanate.

d. Pileus margin roll: straight.

e. Pileus surface on Touch: dry, non hygrophanous.

f. Scales: appressed, cover the entire surface.

g. Colour of the scales: reddish brown.

h. Cuticle: not peeling.

i. Pileus consistency: brittle.

j. Flesh colour: reddish brown, no change in colour on bruishing or handling.

k. Stipe: Attachment: lateral, deep dry blood colour.

1. Size: $4 \mathrm{~cm}$, equal throughout. Stipe base: psudorrhiza.

m. Texture: smooth.

n. Consistency: tough. Stipe Surface: smooth.

o. Stipe context: stuffed.

p. Trama color: brown.

q. Pores: present, white in colour.

r. Habitat: on wood. Association: solitary, present on slopes.

s. Soil characterstics: laterite soil.

t. Forest type: tropical moist deciduous.

u. Vegetational community: thick woody.

v. Distribution: In Odisha, it is distributed in Belghar forest of Baliguda forest division (Figure 4).

\section{Ganoderma australe (Fr.) Pat}

a. Pileus: Diameter: $2 \mathrm{~cm}(\mathrm{av})$.

b. Colour: when young in centre: dark brown. Margin: white; mature specimen: dark brown in colour.

c. Shape: lateral, tuberculate.

d. Pileus margin roll: reflexed.

e. Pileus surface on touch: moist, hygrophanous.

f. Scales: appressed, cover the entire surface.

g. Cuticle: not peeling.

h. Pileus consistency: brittle.

i. Flesh colour: deep brown; no change in colour on bruishing or handling. The lower surface is white in colour. It is very similar to G. applanatum but the size is very small in comparision.

j. Stipe: sessile.

k. Pores: present, white in colour. 
1. Habitat: on tree trunk. Association: scattered, present on slopes.

m. Soil characterstics: laterite soil.

n. Forest type: tropical moist deciduous.

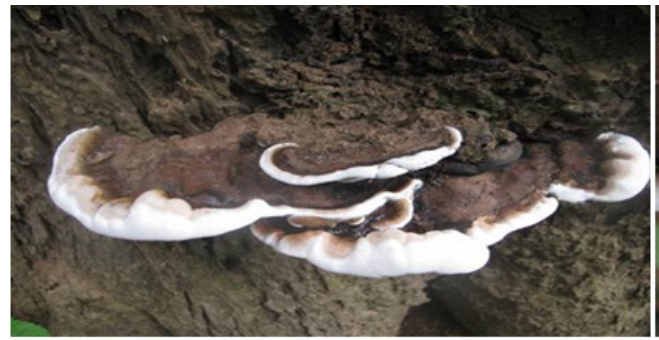

Figure 3 Photograph of Ganoderma applanatum in the field.

Ganoderma applanatum
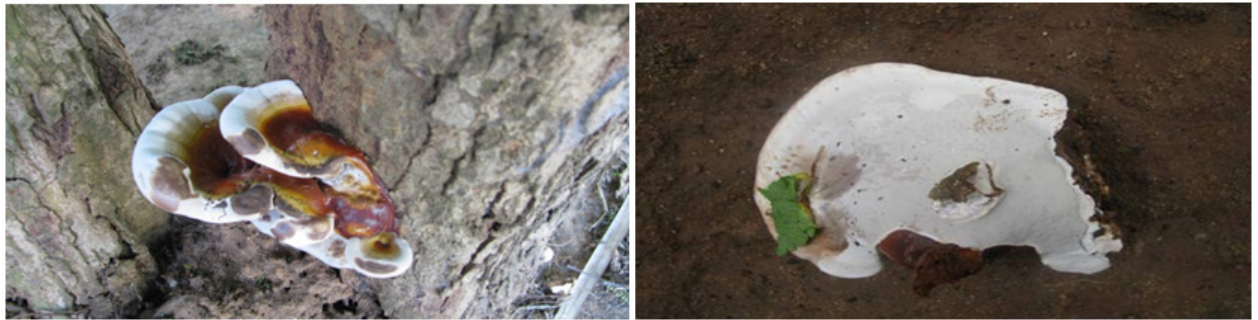

Figure 4 Photograph of Ganoderma tsugae in the field. Ganoderma tsugae

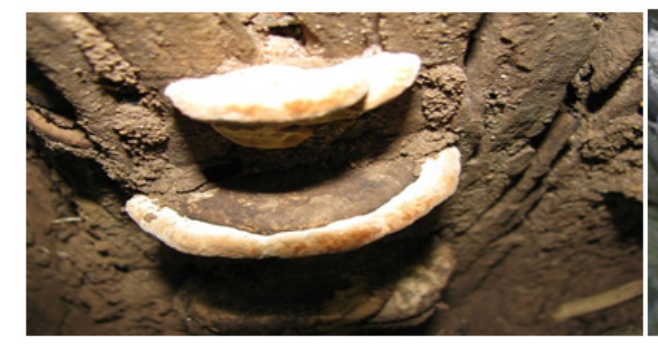

o. Vegetational community: grassland, thick, woody.

p. Distribution: in the buffer areas of Similipal Biosphere Reserve, as well as in Karlapat Sanctuary of south Kalahandi district of Odisha (Figure 5) (Figure 6) (Table 1) (Table 2).
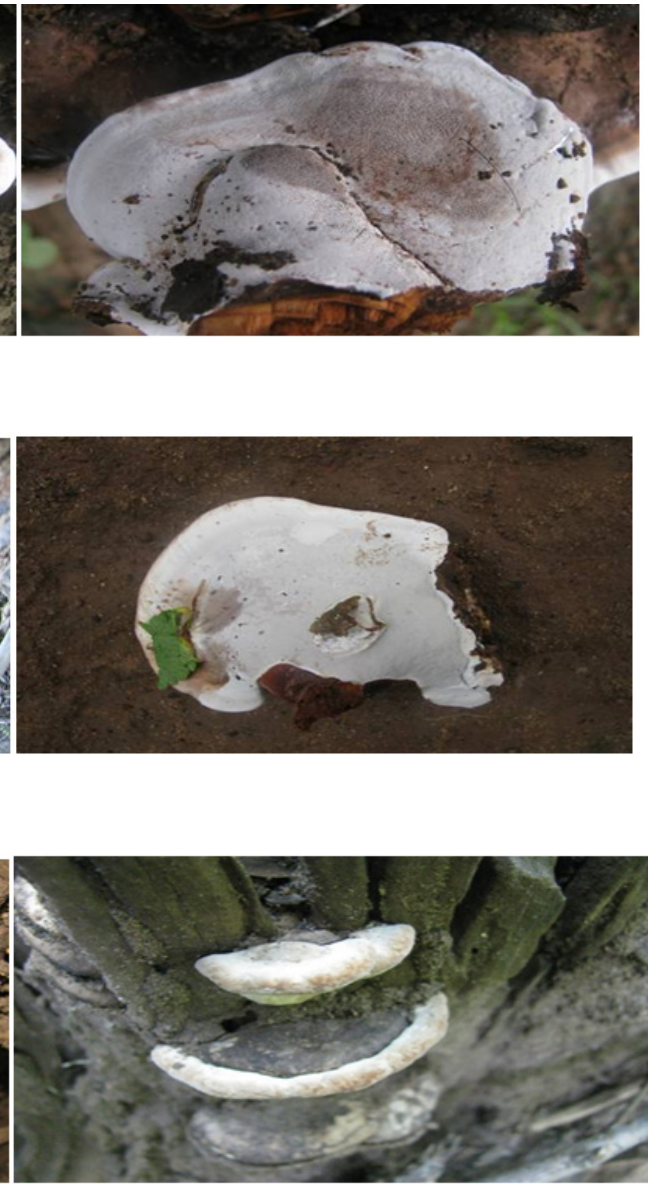

Figure 5 Photograph of Ganoderma australe in the field.

\section{Ganoderma australe}

Table I Distribution of Ganoderma species in five forest areas of Odisha

\begin{tabular}{llllll}
\hline Species & Similipal & Baliguda & Karlapat & Koraput & Banei \\
\hline Ganoderma lucidum (Curtis) P. Karst. & 15 & 12 & 0 & 11 & 0 \\
Ganoderma applanatum (Pers.) Pat. & 12 & 0 & 1 & 16 & 0 \\
Ganoderma tsugae (Kuo, M.) & 14 & 0 & 13 & 12 & 13 \\
Ganoderma australe ( Fr.) Pat. & 5 & 0 & 0 & 11 & 3 \\
\hline
\end{tabular}

Citation: Tripathy SS, Gupta N.A study on genus ganoderma from deciduous forests of Odisha, India.J Bacteriol Mycol Open Access. 20I5; I (2):28-33. DOI: 10.15406/jbmoa.2015.01.00007 
Table 2 Medicinal importance and occurrence of Ganoderma spp., in Odisha

\begin{tabular}{|c|c|c|c|}
\hline $\begin{array}{l}\text { Sp. } \\
\text { no. }\end{array}$ & Scientific name & Medicinal uses & Widely occurrence in moist deciduous forests of Odisha \\
\hline I & $\begin{array}{l}\text { Ganoderma lucidum (Curtis) } \\
\text { P. Karst. }\end{array}$ & $\begin{array}{l}\text { Anti viral, anti diabetic, Anti } \\
\text { fungal, }\end{array}$ & $\begin{array}{l}\text { Similipal Biosphere Reserve: } \\
\text { Kaliyani forests, Chahala, Bareipani, Barahkamuda. } \\
\text { Koraput Forest Division:Adjoining forest to Koraput town, } \\
\text { Baliguda Forest Division: Belghar \& Kotagarh Sanctuary. }\end{array}$ \\
\hline 2 & $\begin{array}{l}\text { Ganoderma applanatum } \\
\text { (Pers.) Pat. }\end{array}$ & Antibacterial, anti tumoral & $\begin{array}{l}\text { Koraput Forest, Belghar Forest, Gurguria forest range of Similipal } \\
\text { Biosphere reserve. }\end{array}$ \\
\hline 3 & Ganoderma tsugae (Kuo, M.) & High Anti tumor activity. & Similipal Forest, Banei Forest, Karlapat Sanctuary, Koraput Forest. \\
\hline 4 & Ganoderma australe (Fr.) Pat. & $\begin{array}{l}\text { Antimicrobial, antioxidative } \\
\text { activity. }\end{array}$ & $\begin{array}{l}\text { Similipal Biosphere Reserve, Koraput Forest Division and Banei } \\
\text { Forest Division. }\end{array}$ \\
\hline
\end{tabular}

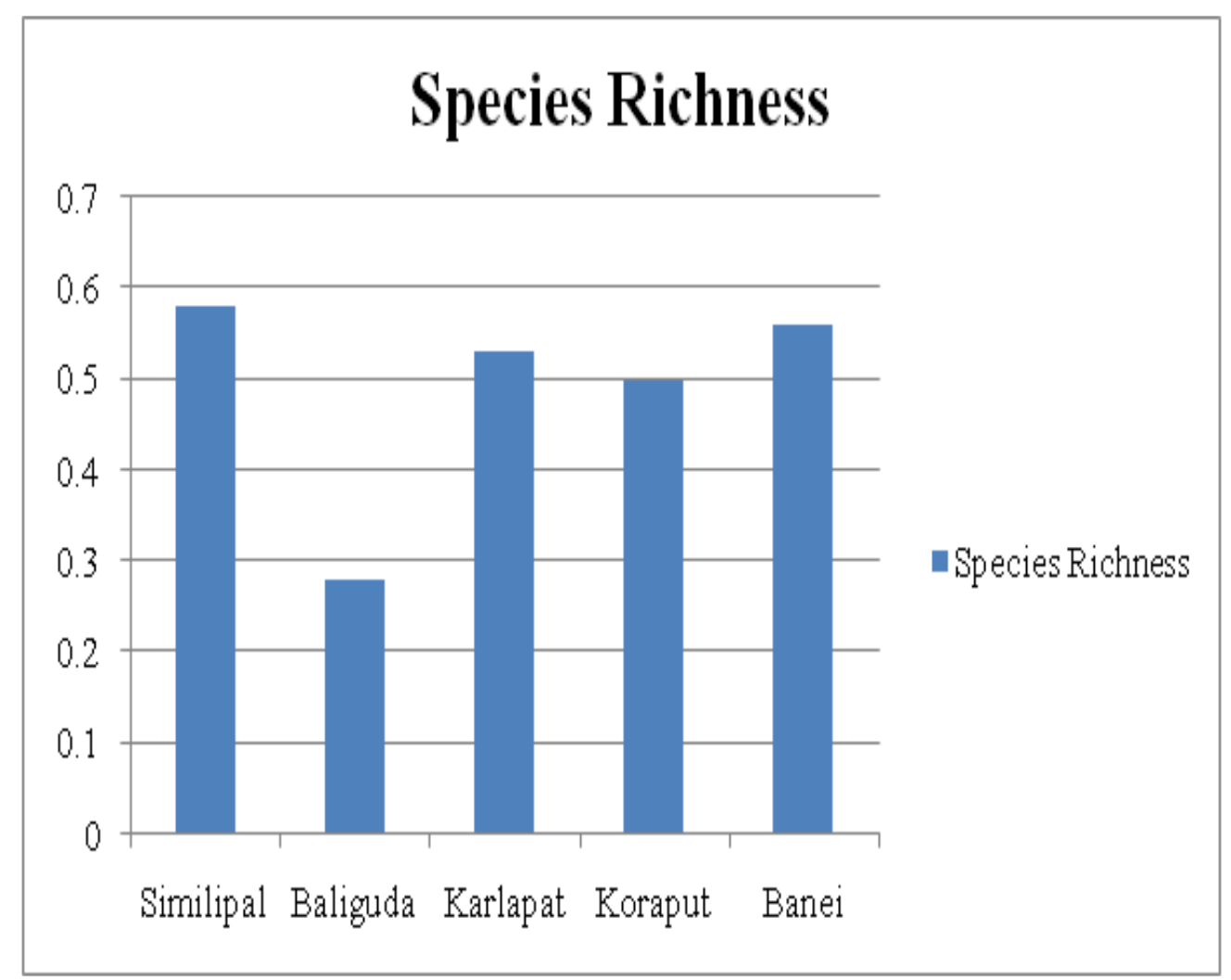

Figure 6 Species richness in five sampling sites. The species richness graph shows Similipal forest has maximum species richness i.e. 0.58 and Baliguda forest has lowest species richness i.e. 0.28. Banei forest (0.56), Karlapat forest (0.53) and Koraput forest $(0.50)$ have almost similar species richness.

In India, Bakshi ${ }^{11}$ contributed to the study of this genus, describing five species. Bilgrami et al., ${ }^{12}$ recorded seven species of Ganoderma in 'Fungi of India'. Whereas some species are reported in different databases/checklists of various states, Bilgrami et al., ${ }^{12}$ reported $G$. annulare, G. adspermum and G. australe from India, and Bakshi ${ }^{11}$ as well as Steyaert ${ }^{13}$ reported G. tronatum but all these species are the synonyms of $G$. australe..$^{14}$ Many reports on taxonomic diversity of Ganoderma species were published from Western Maharastra, Himachal Pradesh and Southern India, but central India was less explored. The present study gives the first report on the diversity of four Ganoderma species from Odisha.

As the extinction of wild macro fungi species has started and progressed rapidly, the problem has not been brought into consideration for conservation. As many trees having mycorrhizal association with wild macro fungi are being cut down due to human interference this is leading to an unfavorable condition for these fungi to grow in their proper habitat. Developing the cultivation of some of these wild medicinal fungi as well as popularizing their pharmacological potential and food value can create a good market for the tribal people as source of seasonal income all over the state. 


\section{Acknowledgements}

None.

\section{Conflict of interest}

The author declares no conflict of interest.

\section{References}

1. Montagne JFC. Cryptogamae Nilgheronsis. Ann Sci Nat-II Ser. 1842;18:12-23

2. Berkeley MJ. Decades XXXIX, Sikkim Himalayan fungi collected by J D Hooker. Journal of Botany. 1851;3:39-49.

3. Donk MAA. Conspectus of the families of Aphyllophorales. Persoonia. 1964;3(2):19-24.

4. Moncalvo JM. Systematics of Ganoderma. In: Ganoderma Diseases of Perennial Crops. UK: CABI; 2000. p. 23-45.

5. Champion HG, Seth SK. A Revised Survey of Forest Types of India. India: Govt. of India Press; 1968. 404 p.

6. Zhao JD, Zhang XQ. Importance, distribution and taxonomy of Ganodermataceae in China. Proceedings of Contributed Symposium, B $5^{\text {th }}$ International Mycological Congress, Vancouver; 1994. p. 14-21.
7. Woo YA, Kim HJ, Cho JH, et al. Discrimination of herbal medicines according to geographical origin with near infrared reflectance spectroscopy and pattern recognition techniques. J Pharm Biomed Anal. 1999;21(2):407-413.

8. Upton R. American Herbal Pharmacopeia and Therapeutic Compendium: Reishi mushroom, Ganoderma lucidum. Standards of Analysis, Quality Control, and Therapeutics. USA: Santa Cruz; 2000.

9. Chang ST, Bushwell JA. Mushroom nutraceuticals. World J Microbiol Biotechnol. 1996;12(5):473-476.

10. Atri NS, Kaur A, Kaur H. Wild Mushrooms: Collection and Identification. Mushroom Res. 2003;14:56-59.

11. Bakshi BK. The Polyporaceae (On Trees and Timber). India: Indian Council of Agriculture Research; 1971. p. 58-62.

12. Bilgrami KS, Jamaluddin S, Rizwi MA. Fungi of India: List and References. India: Today and Tomorrow's Printers and Publishers; 1991. $798 \mathrm{p}$

13. Steyaert RL. Species of Ganoderma and related genera mainly of the Bogor and Leiden herbaria. Persoonia. 1972;7(1):55-118.

14. Moncalvo JM, Ryvarden L. A nomenclatural study of the Ganodermataceae. Synopsis Fungorum 11. Oslo, Norway; 1997. p. 1-114. 